\title{
Muscle spindle function in healthy and diseased muscle
}

\author{
Stephan Kröger *i] and Bridgette Watkins
}

\begin{abstract}
Almost every muscle contains muscle spindles. These delicate sensory receptors inform the central nervous system (CNS) about changes in the length of individual muscles and the speed of stretching. With this information, the CNS computes the position and movement of our extremities in space, which is a requirement for motor control, for maintaining posture and for a stable gait. Many neuromuscular diseases affect muscle spindle function contributing, among others, to an unstable gait, frequent falls and ataxic behavior in the affected patients. Nevertheless, muscle spindles are usually ignored during examination and analysis of muscle function and when designing therapeutic strategies for neuromuscular diseases. This review summarizes the development and function of muscle spindles and the changes observed under pathological conditions, in particular in the various forms of muscular dystrophies.
\end{abstract}

Keywords: Mechanotransduction, Sensory physiology, Proprioception, Neuromuscular diseases, Intrafusal fibers, Muscular dystrophy

In its original sense, the term proprioception refers to sensory information arising in our own musculoskeletal system itself [1-4]. Proprioceptive information informs us about the contractile state and movement of muscles, about muscle force, heaviness, stiffness, viscosity and effort and, thus, is required for any coordinated movement, normal gait and for the maintenance of a stable posture. Proprioception combines with other sensory systems to locate external objects relative to the body and by this contributes to our body image and equilibrioception. Since proprioception is vital for motor and body control, patients with a loss of proprioception either due to an autoimmune disease [5] or due to a lossof-function mutation in a protein essential for proprioception [6] have prominent sensory and motor deficits, generally leading to ataxia and dysmetria. Patients with a congenital absence of proprioception show delayed

\footnotetext{
* Correspondence: skroeger@lmu.de

Department of Physiological Genomics, Biomedical Center,

Ludwig-Maximilians-University Munich, Großhaderner Str. 9, 82152

Planegg-Martinsried, Germany
}

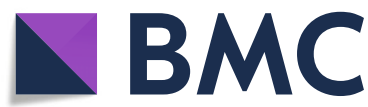

(c) The Author(s). 2021 Open Access This article is licensed under a Creative Commons Attribution 4.0 International License, which permits use, sharing, adaptation, distribution and reproduction in any medium or format, as long as you give appropriate credit to the original author(s) and the source, provide a link to the Creative Commons licence, and indicate if changes were made. The images or other third party material in this article are included in the article's Creative Commons licence, unless indicated otherwise in a credit line to the material. If material is not included in the article's Creative Commons licence and your intended use is not permitted by statutory regulation or exceeds the permitted use, you will need to obtain permission directly from the copyright holder. To view a copy of this licence, visit http://creativecommons.org/licenses/by/4.0/ The Creative Commons Public Domain Dedication waiver (http://creativecommons.org/publicdomain/zero/1.0/) applies to the data made available in this article, unless otherwise stated in a credit line to the data. pairment of fine motor skills, sensory ataxia with unsteady gait, increased stride-to-stride variability in force and step length, an inability to maintain balance with eyes closed (Romberg's sign), a severely reduced ability to identify the direction of joint movements, and an absence of tendon reflexes [6-12]. The motor problems are so severe that without the compensatory activity of other senses, including the vestibular and the visual systems, the patients are unable to maintain their posture, walk or perform coordinated voluntary movements. In addition, recent studies have uncovered exciting new functions for proprioception [4, 13]. For example, proprioceptive information is required for the realignment and proper healing of fractured bones [14] as well as for the maintenance of spine alignment [15]. Thus, patients with proprioceptive deficits are likely to develop adolescent idiopathic scoliosis in their second decade of life, suggesting that the proprioceptive information may not only provide dynamic control of spine alignment but also prevent progressive spinal deformation [13, 15]. 
Moreover, after spinal cord injury, proprioceptive feedback is essential for locomotor recovery and facilitates circuit reorganization [16]. Ablation of this feedback after behavioral recovery permanently reverts functional improvements, demonstrating the essential role of proprioception also for maintaining regained locomotor function [17]. Thus, proprioceptive information has functions that extend far beyond motor control and includes non-conscious regulation of skeletal development and function as well as recovery after spinal cord injury $[4,18]$.

\section{Structure and function of muscle spindles}

Although Golgi tendon organs, joint receptors and other sensory systems also contribute to proprioception, muscle spindles are the most important proprioceptors $[19,20]$. Muscle spindles are the most frequently found sense organs in skeletal muscles and present in almost every muscle. The density of muscle spindles within the large muscle mass, however, is low so that they are rather difficult to detect. Rough estimates have suggested approximately 50,000 muscle spindles in the entire human body [21]. Interestingly, in humans, muscle spindles are mostly absent in facial muscles [22] and extraocular muscles have unusual muscle spindles and additional unique sensory structures named palisade endings, which might also provide proprioceptive information [23-25].

Muscle spindles are encapsulated sensory receptors which inform the brain about changes in the length of muscles $[3,20]$. They consist of specialized muscle fibers (so called intrafusal fibers) that are multiply innervated and named according to the arrangement of their nuclei as nuclear bag or nuclear chain fibers (a schematic representation of a muscle spindle is shown in Fig. 1a). Intrafusal muscle fibers are up to 8-mm long in humans and about $400-\mu \mathrm{m}$ long in mice and oriented parallel to the surrounding (extrafusal) muscle fibers. Each muscle spindle contains on average 3-5 (mouse) [28] or 8-20 (human) [29] intrafusal fibers. With a diameter of 8 to $25 \mu \mathrm{m}$ [30], intrafusal muscle fibers are much thinner than extrafusal muscle fibers. Contractile filaments are found in intrafusal fibers predominantly in the polar regions with only a small ring of sarcomeres underneath the sarcoplasmic membrane in the central (equatorial) region (Fig. 1a). However, muscle spindles do not contribute significantly to the force generated by the muscle $[31,32]$. Nuclear bag fibers often extend beyond the fluid-filled fusiform capsule and are attached to intramuscular connective tissue [33]. Nuclear chain fibers are

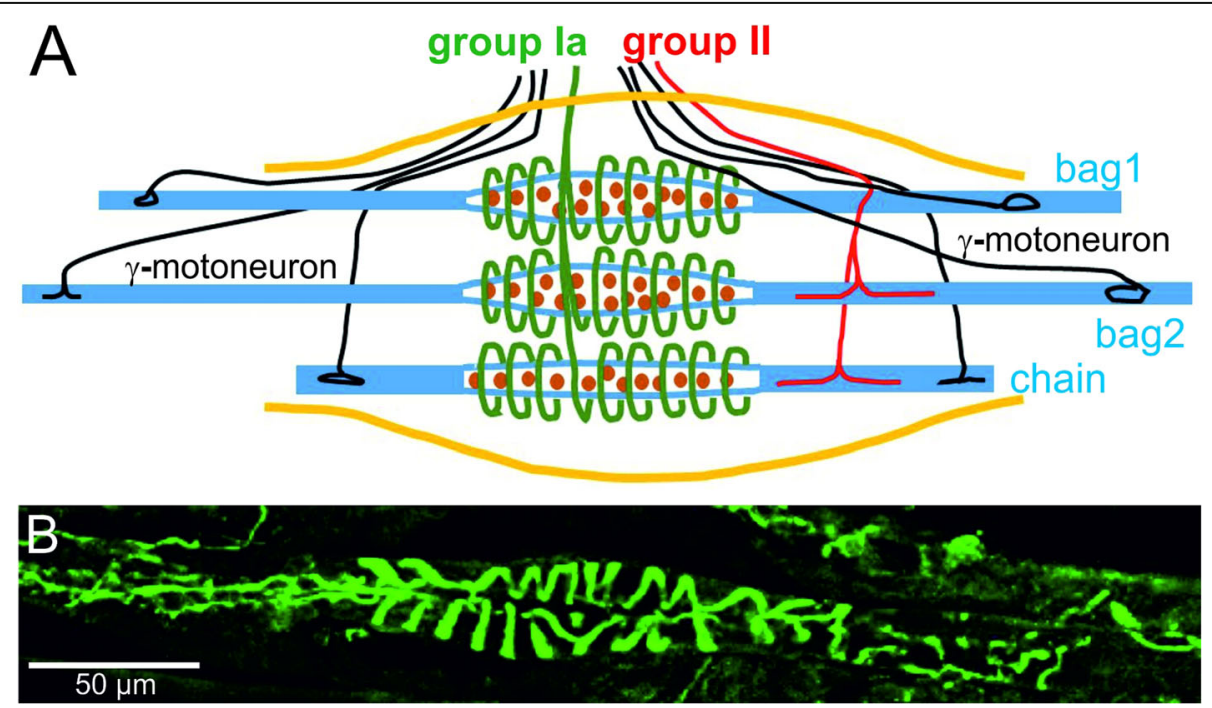

Fig. 1 Structure of muscle spindles and distribution of the DGC. Panel a shows a schematic representation of the sensory and fusimotor innervation of intrafusal fibers. The connective tissue capsule is indicated in orange. Muscle spindles contain three types of intrafusal fibers: nuclear bag1, nuclear bag2, and nuclear chain fibers. Different parts of intrafusal fibers are innervated by different neurons: The central (equatorial) part is in intimate contact with afferent proprioceptive sensory neurons, termed primary "group la afferents" (forming the annulospiral endings) and (if present) secondary or "group II afferents", marked in green and red, respectively. In addition to the sensory neurons, intrafusal muscle fibers are innervated by efferent $\gamma$-motoneurons (marked in black) in both polar regions, were they form a cholinergic synapse. The polar regions of intrafusal fibers contain most of the contractile elements (sarcomeres are indicated in blue in panel a). This schematic representation is based on the well-characterized muscle spindles from the cat's tenuissimus muscle [19]. However, interspecies differences exist. For example, mouse muscle spindles might not have a group II innervation [26], and in humans, the sensory nerve terminal does not form annulospiral endings and the secondary ending innervates nuclear bag as well as nuclear chain muscle fibers [27]. Panel $\mathbf{b}$ shows a confocal section of the central part of a mouse muscle spindle stained with anti-neurofilament antibodies. Note the annulospiral endings of the la afferents in the central region. The $\mathrm{y}$-motoneuron endplates are located outside the picture 
attached to the polar regions of the thicker and longer nuclear bag fibers [33].

Functionally, muscle spindles are stretch detectors, i.e. they sense how much and how fast a muscle is lengthened or shortened [19]. Accordingly, when a muscle is stretched, this change in length is transmitted to the spindles and their intrafusal fibers which are subsequently similarly stretched. To respond appropriately to changes in muscle fiber length, intrafusal fibers are innervated by two kinds of neurons: afferent sensory neurons and efferent motoneurons (Fig. 1a). In humans, the sensory innervation of the muscle spindle arises from both group Ia and group II afferent fibers (also sometimes called type Ia or type II fibers, respectively), which differ in their axonal conduction velocity [34]. In contrast, in mice an innervation by group II fibers has so far not been detected by histological or functional assays $[26,35]$. However, transcriptome analysis of DRG proprioceptive neurons has recently suggested the existence of group II fibers also in mice [36]. There is usually only a single Ia afferent fiber per spindle, and every intrafusal muscle fiber within that spindle receives innervation from that sensory neuron. In cat, rat and mice (and probably many other species), the axon terminals of this sensory afferent fiber coil around the central (equatorial) part of both nuclear bag and nuclear chain fibers, forming the primary endings (also called annulospiral endings) [37, 38] (Fig. 1b). In humans, sensory terminals form irregular coils with branches and varicose swellings
[39]. When present, the smaller group II fiber terminals flank the primary annulospiral endings in the equatorial region (Fig. 1a). There may be several group II fibers innervating each human spindle [40]. The cell bodies of these proprioceptive afferent fibers constitute $5-10 \%$ of all neurons in the dorsal root ganglion [36]. They can be classified and distinguished from other dorsal root ganglion neurons as a unique neuronal population using single cell transcriptome analysis [36, 41, 42].

Afferent sensory neurons generate action potentials with frequencies that correspond to the size of the stretch and to the rate of stretching [43] (Fig. 2). Sensory neurons innervating bag1 fibers respond maximally to the velocity of changes in muscle fiber length (dynamic sensitivity) and those innervating bag2 fibers as well as nuclear chain fibers respond maximally to the amount of stretch (static sensitivity). For a recent review on the mechanotransduction processes within the sensory nerve terminal, see [45].

Sensory neuron activity from muscle spindles can be electrophysiologically recorded and characterized in a number of different ways. In humans, for example, individual sensory afferent ("single unit") action potentials can be studied in vivo by intraneural microelectrodes inserted into accessible peripheral nerves (microneurography), such as the median and ulnar nerves at the wrist or upper arm, the radial nerve in the upper arm, and the tibial and common peroneal nerves in the lower limb [29]. In mice, single unit muscle spindle afferent

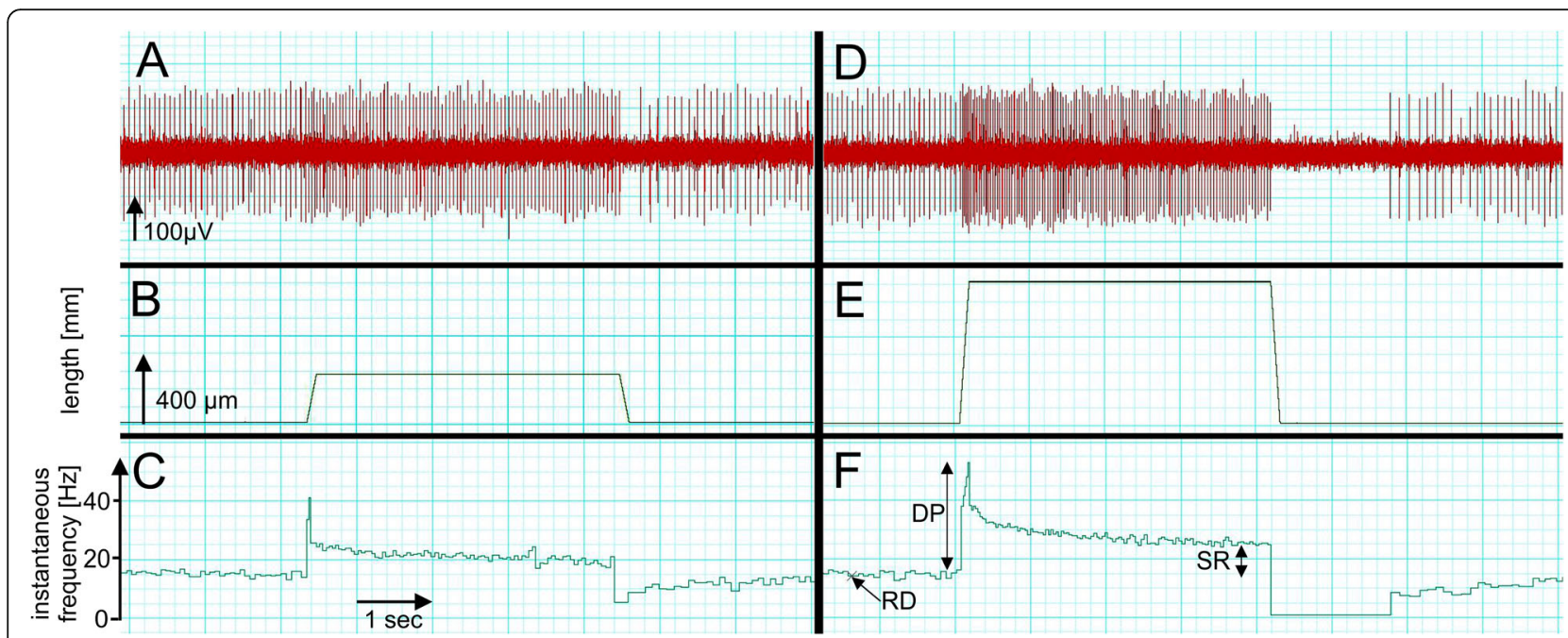

Fig. 2 Typical responses of a muscle spindle to stretch. The responses of an individual muscle spindle from the mouse extensor digitorum longus muscle to ramp and hold stretches applied to the tendon were recorded with an extracellular electrode. Single unit action potentials are shown in (a and $\mathbf{d}$ ). The stretch was 4-s long, and the length change corresponded to 260 (panel b) and 780 (panel e) $\mu \mathrm{m}$. The ramp speed in (e) was 3fold higher compared to that in (b). Panels $\mathbf{c}$ and $\mathbf{f}$ represent the instantaneous frequencies (action potentials/s). In panel $\mathbf{f}$, three different parameters that are usually analyzed to describe muscle spindle function are illustrated: resting discharge (RD), dynamic peak (DP), and static response (SR). For more information on these parameters, see [32, 33, 44]. Note that the dynamic peak and the static response is higher in (f), compared in (c) due to the higher ramp speed and the longer length change. Since the fusimotor innervation was cut during the dissection of the muscle, no action potentials can be observed directly after the end of the ramp and hold stretch (spindle pause) 
responses to ramp-and-hold stretches and sinusoidal vibratory stimuli have been well characterized in an ex vivo adult mouse extensor digitorum longus preparation dissected with the innervating nerve attached [26, 46]. A typical example for a single unit muscle spindle response to two different ramp-and-hold stretches in the adult mouse extensor digitorum longus muscle is shown in Fig. 2. In many species, muscle spindles exhibit a resting discharge that is related to the degree of muscle stretch but the frequency of the mean firing rate differs between species. In mice at room temperature, the frequency is $\sim 15 \mathrm{~Hz}$ (Fig. 2). Muscle spindle afferents encode muscle length in their frequency of firing, i.e. the more the muscle is stretched, the higher the frequency (static response). In addition to the static encoding of length changes, spindle afferents, especially primary afferents, can respond to dynamic length changes, i.e. the faster the stretch, the higher the frequency during the ramp phase. Accordingly, the instantaneous frequency (action potentials/s) shown in Fig. 2 is higher the faster the stretch is and the longer the length change is.

In addition to sensory neurons, intrafusal muscle fibers are also innervated by efferent motoneurons (fusimotor innervation; Fig. 1a) [47]. Both $\beta$ - and $\gamma$-motoneurons innervate intrafusal fibers, but $\gamma$-motoneurons are considerably more abundant and much better characterized compared to $\beta$-motoneurons [48]. Gamma-motoneurons constitute about $30 \%$ of all motoneurons in the ventral horn of the spinal cord. Axons of motoneurons usually enter the spindle together with the sensory fibers in the central region but innervate intrafusal muscle fibers exclusively in the polar regions. The endplates of $\gamma$ motoneurons differ structurally from the neuromuscular junctions formed by $\alpha$-motoneurons on extrafusal fibers, but both are cholinergic synapses with many features in common, including junctional folds and a basal lamina filling the synaptic cleft [47]. Moreover, both synapses require the extracellular matrix synapse organizer agrin and its receptor complex (consisting of the low-density lipoprotein receptor-like protein 4 and the tyrosine kinase MuSK) for their formation, suggesting a common molecular basis for their synaptogenesis [49]. Gammamotoneurons induce contractions of sarcomeres in the polar region to exert tension on the central region of intrafusal fibers $[47,50]$. This prevents the slackening of intrafusal fibers during muscle shortenings and allows for continuous adjustment of the mechanical sensitivity of spindles over the wide range of muscle lengths and stretch velocities that occur during normal motor behaviors.

\section{Muscle spindle development and ageing}

Muscle spindle development starts during embryonic stages but continues well into adult life [51]. Human muscle spindles can be recognized in fetal tissue around the 11th week of gestation [52,53], but little is known about the molecular basis of human muscle spindle development. In contrast, muscle spindle development is much better characterized in rodents, where muscle spindle differentiation begins around embryonic day 14 when the growth cone of the sensory neuron's axon reaches its target muscle. Fusimotor innervation develops a few days later and is present in mice at E19 [54]. In rodents and humans, immature myotubes are induced to differentiate into intrafusal fibers when sensory afferent axons contact the primary myotubes [55-57]. Apparently, nuclear bag fibers differentiate before nuclear chain fibers in rats $[58,59]$. There is the possibility of a hyperinnervation of intrafusal fibers with subsequent pruning of the terminals for the fusimotor innervation [60] as well as for the sensory innervation [61] of rat muscle spindles. In mice, the intrafusal fibers are initially surrounded by a "web-like" network of sensory axons, which is reduced to an adult primary ending from a single sensory neuron (Fig. 3). Human muscle spindles are functional at birth, but their response to stretch is immature [30]. Moreover, with the postnatal increase in muscle mass and mobility, sensory nerve terminals in mice and humans undergo a number of anatomical and physiological changes [62-64]. By postnatal day 18, muscle spindle afferent firing is indistinguishable from the firing in adult rats suggesting that muscle spindle maturation continues into postnatal life and that muscle spindles are capable of responding to stretch, even at an age when their morphological and ultrastructural maturation is not yet fully accomplished [65].

After the establishment of a physical contact between the sensory axon and the primary myotube, both cells exchange inductive signals ensuring the differentiation of intrafusal fiber and the survival of the sensory neuron. This reciprocal signaling is essential for muscle spindle differentiation and intrafusal fiber development. Accordingly, elimination of the sensory input (but not of the fusimotor input) in embryonic and adult muscle spindles results in a rapid degeneration of the intrafusal fibers ([66-68]; for review, see [55]). The key inductive factor for the sensory neuron-mediated muscle spindle differentiation is the immunoglobulin form of neuregulin-1 (Ig-Nrg1). Ig-Nrg1 is expressed by proprioceptive neurons $[69,70]$, and its release from sensory neurons and subsequent binding to the ErbB2 receptor expressed by immature muscle fibers [71] induces their differentiation into intrafusal muscle fibers. Accordingly, Nrg1- or ErbB2-deficient mice do not initiate muscle spindle differentiation, do not elaborate Ia afferent terminals and have an ataxic behavior as well as abnormal hind limb reflexes, consistent with severe proprioceptive deficits [69-72]. Nrg1-ErbB2 signaling activates downstream 

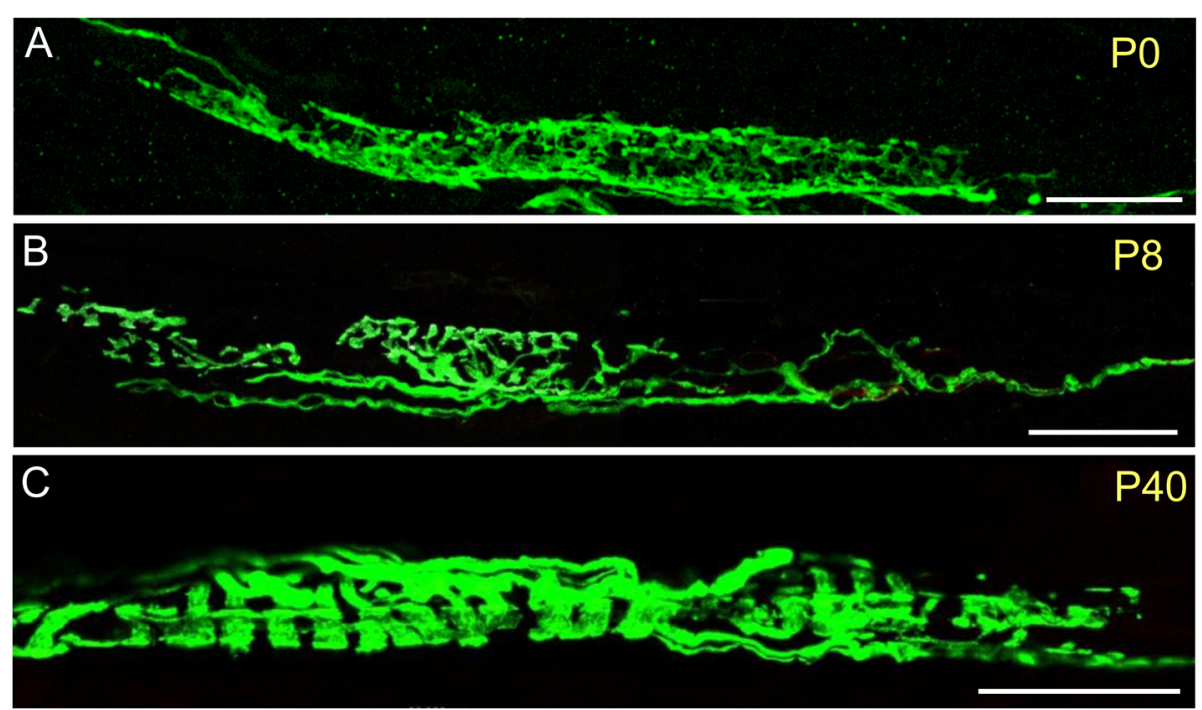

Fig. 3 Postnatal development of mouse muscle spindles. Muscle spindles from postnatal day 0: P0 (a), P8 (b), and P40 (c). Thy1-YFP mouse extensor digitorum longus were stained with anti-GFP antibodies. Only the central (equatorial) region is shown. Note the transformation of the "web-like" appearance of the sensory nerve terminal into the typical annulospiral ending during postnatal development. Scale bar in all panels: $50 \mu \mathrm{m}$

targets such as the transcription factor early growth response protein 3 (Egr3) [73-75], and the Ets transcription factors Pea3, Erm and Er81 as well as the Grb2associated binder 1 protein, a scaffolding mediator of receptor tyrosine kinase signaling [69, 76, 77]. Although muscle spindles are initially generated in Egr3-deficient mice [75], subsequently most of them degenerate, resulting in ataxic behavior [73, 74]. Overexpression of Egr3 in primary myotubes on the other hand leads to their differentiation into intrafusal fibers [78], suggesting that this transcription factor is necessary and sufficient for muscle spindle maintenance. Interestingly, Ig-Nrg1 is the substrate for the membrane-bound aspartyl protease Bace1 (also called $\beta$-secretase 1). Cleavage of Ig-Nrg1 is required for Ig-Nrg1 function and, accordingly, in the absence of Bace1, muscle spindle numbers are reduced and spindle maturation is impaired. Moreover, a graded reduction in Ig-Nrg1 signal strength in vivo induced by pharmacological Bace1 inhibition results in increasingly severe deficits in the formation and maturation of muscle spindles in combination with a reduced motor coordination [70]. The continuous presence of Bace1 and Ig-Nrg1 is essential to maintain muscle spindles in adult muscle, since either pharmacological inhibition of Bace1 or induced Bace1 deficiency in adult proprioceptive neurons also leads to a decline of muscle spindle number [70]. In summary, the sensory neuron induces the differentiation of muscle spindles from immature myotubes via Ig-Nrg1, Bace1 and ErbB2-mediated activation of Egr3.
On the other hand, muscle fibers release neurotrophin-3 (NT3), which activates the tropomyosin receptor kinase $\mathrm{C}(\mathrm{TrkC})$ receptor on proprioceptive sensory neurons and by this secures the survival of the sensory neuron [79-81]. The TrkC/NT3 signaling system is, however, not required for the initiation of muscle spindle differentiation [82]. Muscle-specific overexpression of NT3 results in an increase in the number of proprioceptive afferents and muscle spindles [83-85]. NT3/ TrkC signaling induces the expression of the Etv1 (Er81) transcription factor in proprioceptive sensory neurons $[76,86]$. Interestingly, the survival of proprioceptive sensory neurons supplying distinct skeletal muscles differ in their dependence on Etv1 for their survival and differentiation [87]. The survival and/or specification of the TrkC-positive proprioceptive afferents also requires the expression of the Runt-related transcription factor 3 (Runx3) and Runx3-knockout mice display severe limb ataxia due to absence of proprioceptive sensory neurons [88, 89].

As in the musculoskeletal system in general, various elements of the proprioceptive system decline during ageing [90, 91]. These changes might contribute to the frequent falls and motor control problems observed in older adults. On the structural level, muscle spindles in aged humans possess fewer intrafusal fibers, an increased capsular thickness and some spindles which show signs of denervation $[92,93]$. In old rats, primary endings are less spiral or non-spiral in appearance, but secondary endings appeared unchanged [94, 95]. Likewise, in old 
mice, there is a significant increase in the number of Ia afferents with large swellings that fail to properly wrap around intrafusal muscle fibers. There is also a degeneration of proprioceptive sensory neuron cell bodies in the dorsal root ganglion but no change in the morphology and number of intrafusal muscle fibers [96]. In addition, electrophysiological studies showed that mature rat muscle spindles display a lower dynamic response of primary endings compared with those of young animals [94]. Taken together, the proprioceptive system undergoes significant structural and functional changes with advancing age and the changes are consistent with a gradual decline in proprioceptive function in elderly individuals and animals.

\section{Muscle spindle structure and function in muscular dystrophy}

An impaired proprioception, in some cases associated with an altered muscle spindle morphology, has been documented as a secondary effect in many diseases. These include Parkinson's disease [97], Huntington's disease [98], multiple sclerosis [99], Charcot-Marie-Tooth type $2 \mathrm{E}$ [100], traumatic or neurotoxic injury [101], spinal muscular atrophy [102], diabetic neuropathy [103, $104]$ and myasthenia gravis $[105,106]$. In amyotrophic lateral sclerosis, sensory neurons are similarly affected as $\alpha$-motoneurons [107-110]. They accumulate misfolded SOD1 protein and the annulospiral endings degenerate, leading to ataxia and motor control problems $[107,109]$. In contrast to $\alpha$-motoneurons, $\gamma$-motoneurons apparently survive degeneration in murine models of amyotrophic lateral sclerosis and spinal muscular atrophy [111-113], suggesting differential vulnerabilities for both types of motoneurons in both diseases.

Recently, a number of studies have analyzed proprioception and muscle spindle function in patients with muscular dystrophy and in dystrophic mouse models. Muscular dystrophies are a heterogeneous group of more than 30 different mostly inherited diseases characterized by muscular weakness and atrophy in combination with degeneration of the musculoskeletal system [114]. The molecular basis of many muscular dystrophies are mutations that directly or indirectly influence the function of the dystrophin-associated glycoprotein complex (DGC) $[115,116]$. The most common form of muscle dystrophy in humans is Duchenne muscular dystrophy (DMD) which affects approximately 1 in 5000 boys [117]. DMD is caused by mutations in the $D M D$ gene, which codes for the large cytoskeletal protein dystrophin [114]. In skeletal muscle, dystrophin links subsarcolemmal F-actin filaments to the extracellular matrix via the DGC $[118,119]$. This link mechanically stabilizes the sarcolemmal membrane particularly during muscle contraction. Mutations which cause an interruption of the dystrophin/DGC-mediated molecular connection lead to mechanical lability of the sarcolemmal membrane and subsequent contraction-induced damage [114, 120-122]. While regeneration of damaged muscle fibers occurs initially, it cannot compensate for the prolonged degenerative loss of muscle tissue [123], leading over time to a reduction of muscle mass, loss of contractile force and, in the case of DMD, to premature death of the affected person due to respiratory or cardiac muscle failure [124].

Many muscular dystrophy patients suffer from postural instability, sudden spontaneous falls and poor manual dexterity [125-128], suggesting that their proprioceptive system might be impaired. However, only minor morphological changes in muscle spindles were detected in human dystrophic muscles. These changes primarily affect the connective tissue surrounding intrafusal fibers. For example, thickening of the capsule and of the connective tissue septa inside the spindle and an "oedematous swelling" of the spindle were reported in muscle biopsy specimens from Duchenne- and limb-girdle muscular dystrophy patients [106]. Likewise, analyses of biopsy specimens from patients with muscular dystrophy and with congenital dystrophy revealed an increased thickness of the spindle capsule and a slight decrease of the intrafusal fiber diameter [129]. An autopsy study of seven DMD patients aged 15 to 17 years reported more severe pathological changes including degenerative changes, atrophy and loss of intrafusal muscle fibers [130], but it is unclear if these more extensive changes were caused by the disease or due to postmortem tissue degeneration. This possibility has to be considered, since proprioceptive functions of muscle spindles in DMD patients appear rather normal (see below) and since a recent study analyzing muscle spindles from a 27-year-old severely affected DMD patient described that spindle size and number as well as the size of intrafusal myofibers and capsule thickness were in the normal range [131]. Interestingly, the extrafusal fibers directly surrounding the muscle spindles were also less affected by the degenerative events compared to fibers further away from the spindle, suggesting the possibility of a more protective environment directly around muscle spindles.

Likewise, murine models for several muscular dystrophies display only minor changes in muscle spindle structure compared to wildtype control mice. For example, muscle spindles in the soleus muscle from 1year-old $\mathrm{C} 57 \mathrm{BL} / 6 \mathrm{~J}^{\mathrm{dy}-2 \mathrm{~J} / \mathrm{dy}-2 J}\left(\mathrm{Lama2}^{\mathrm{dy} 2 J / \mathrm{dy} 2 J}\right)$ dystrophic mice, a model for laminin $\alpha 2$ (merosin)-deficient congenital muscular dystrophy, had a small but significant increase in the diameter of the outer capsule and in the overall thickness of the equatorial region [132]. But, as in the corresponding patients, intrafusal fibers and sensory terminals appeared mostly spared from degeneration [44, 132]. Similarly, the DMD ${ }^{m d x}$ mouse line [133], 
a widely used model system for muscular dystrophy of the Duchenne type [134], revealed no reduction of the total number of muscle spindles and no change in the structure of muscle spindles and their sensory innervation $[135,136]$. Thus, compared to extrafusal muscle fibers, the morphology of intrafusal muscle fibers and of muscle spindles generally appear much less affected by the degenerative processes in humans and in mice with Duchenne-type muscular dystrophy.

The mechanism(s), which protect intrafusal myofibers from degeneration and wasting, are unknown. Capsular thickening in the equatorial region may be an adaptive response, preventing the intrafusal fibers from undergoing atrophy. Another explanation for the sparing of muscle spindles in DMD patients could be a better maintenance of the intracellular calcium homeostasis similar to what has been described for extraocular muscles [137]. Furthermore, the mild phenotypic effect of the dystrophin mutations might be due to the different surface-to-volume ratio, compared to extrafusal fibers. Intrafusal fibers are thinner compared to extrafusal fibers, have a much smaller mechanical burden, and generate considerably less contractile force. They are therefore less likely to suffer from mechanical damage [138].

Immunohistochemical analysis showed that dystrophin is present in the sarcolemma of the polar regions of intrafusal fibers [139]. In contrast, in the equatorial region, dystrophin is absent from that part of the intrafusal fiber, which is in contact with the sensory nerve terminal but concentrated in parts without sensory nerve contact [136, 139] (Fig. 4a-d). Other proteins of the DGC (including alpha-dystrobrevin1; Fig. 4k) have a similar distribution. The area, where the DGC is concentrated, also corresponds to the region where the intrafusal fiber has direct contact to the basal lamina. The interaction of DGC components with basal lamina proteins might stabilize and help to maintain the subcellular concentration of the DGC in this region of the intrafusal fiber. In any case, the unusual distribution of DGC components indicates a molecular specialization in particular regions of the intrafusal fiber plasma membrane.

As expected, dystrophin is absent in intrafusal fibers of $\mathrm{DMD}^{m d x}$ mice [136] (Fig. 4e-g). However, utrophin expression is markedly upregulated and has a similar distribution in $\mathrm{DMD}^{m d x}$ mice as dystrophin in wildtype mice [136] (Fig. 1e-j). Utrophin is an autosomally encoded paralogue of dystrophin [136]. It shares more than $80 \%$ amino acid sequence similarity to dystrophin, has a similar domain structure and like dystrophin can interact with actin filaments and with DGC components [140]. In skeletal muscle, utrophin is highly expressed in fetal and regenerating muscle fibers [141, 142]. In adult wildtype muscle fibers, utrophin is replaced by dystrophin along the entire sarcolemmal membrane but remains present at the neuromuscular junction, the myotendinous junction and blood vessels [143-146]. In extrafusal muscle fibers from $\mathrm{DMD}^{m d x}$ mice, utrophin is greatly upregulated and present along the entire sarcolemma $[147,148]$. The upregulation of utrophin expression in extrafusal muscle fibers can lessen or even prevent the dystrophic phenotype in $\mathrm{DMD}^{m d x}$ mice and muscular dystrophy patients [149-153]. The upregulation of utrophin in intrafusal fibers of $\mathrm{DMD}^{m d x}$ mice might therefore functionally compensate for the absence of dystrophin and prevent the degeneration of intrafusal fibers. However, intrafusal muscle fibers from DMD patients are utrophin-negative [131], suggesting that the upregulation of this protein cannot solely explain the preservation of intrafusal muscle fibers in humans.

An obvious question arising from these observations is whether the relatively minor structural changes in muscle spindles from DMD patients and corresponding mouse models are accompanied by functional changes. Analysis of single unit sensory afferent recordings from $\mathrm{DMD}^{m d x}$ mice showed that muscle spindles have a normal response to ramp-and-hold stretches and only a slightly increased response to sinusoidal vibrations [136]. More strikingly, the resting discharge, i.e. the action potential frequency of sensory afferents from a resting muscle spindle (Fig. 2), was significantly increased in $\mathrm{DMD}^{m d x}$ mice compared to control mice. This increase in the resting discharge might be clinically relevant since it would cause an increased muscle tone via the muscle stretch reflex, which would lead to an increase in muscle stiffness and an aggravation of the degenerative events in extrafusal fibers of DMD patients.

Interestingly, a similar increase of the resting discharge was observed in SJL-Dysf C57BL/6 $\left(d y s f^{-1-}\right)$ mice [136], a murine model system for dysferlinopathies $[154,155]$. Dysferlinopathies (including limb girdle muscular dystrophy 2B and Miyoshi myopathy) are muscular dystrophies characterized by muscle weakness and wasting but differ from DMD in the molecular etiology and disease progression [156]. They are caused by mutations in the DYSF gene that impair the function of dysferlin [157159], a single pass transmembrane protein with important roles in membrane fusion and trafficking [156, 160, 161]. When microlesions in the plasma membrane occur, vesicles are recruited to the injury site and dysferlin then appears to participate in the resealing of the injury site by promoting vesicle aggregation and fusion with the plasma membrane $[162,163]$. Accordingly, loss of dysferlin leads to an impaired membrane repair and degeneration of skeletal muscle fibers, causing the muscle weakness. Additional functions of dysferlin, including an impaired $\mathrm{Ca}^{2+}$ homeostasis during mechanical stress [164], might contribute to the degeneration of skeletal muscle. Like in the $\mathrm{DMD}^{m d x}$ mouse, muscle 

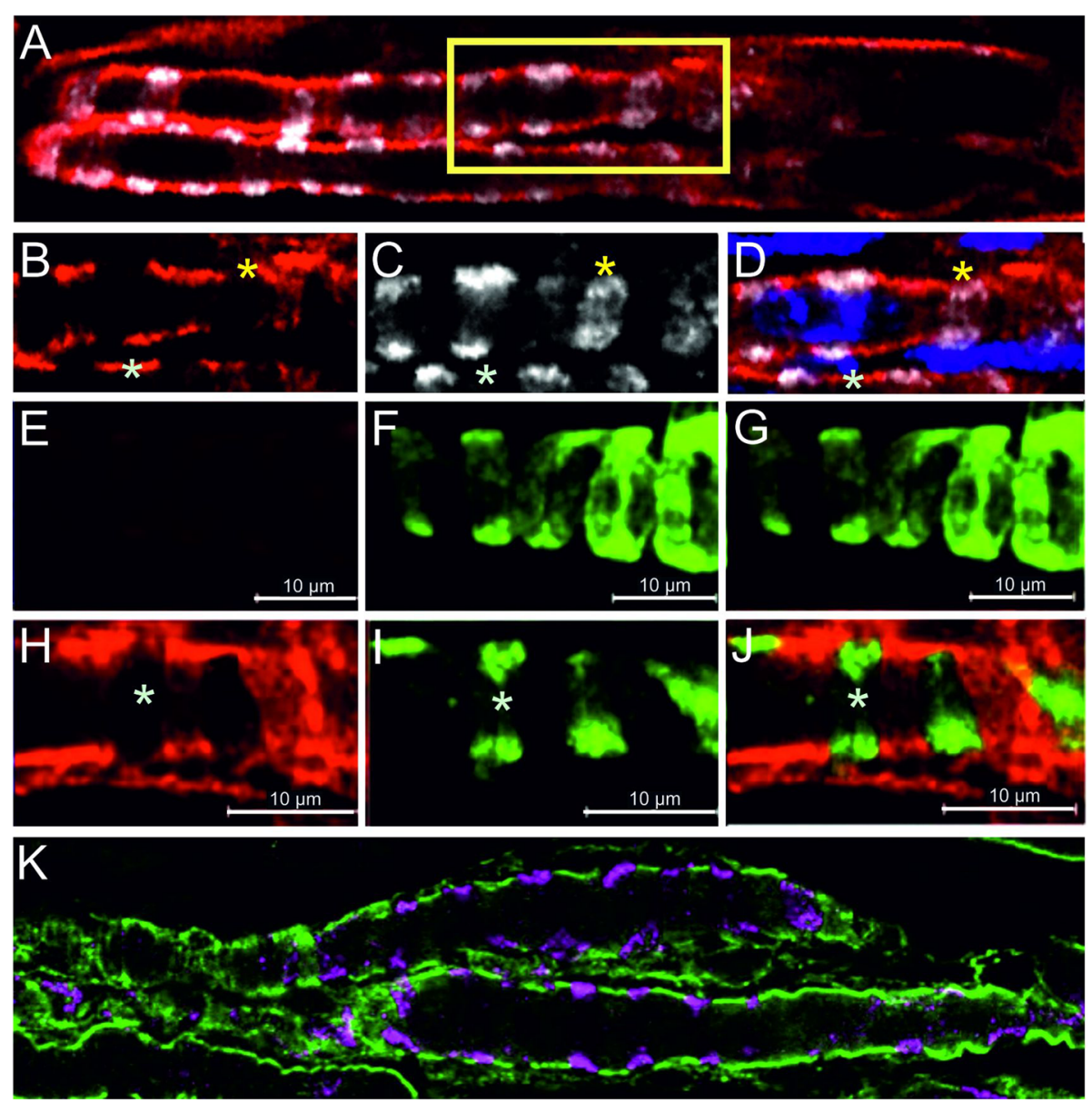

Fig. 4 Distribution of the dystrophin glycoprotein complex in mouse intrafusal fibers. Panel a shows two intrafusal fibers labeled by antidystrophin antibodies (red channel) and by antibodies against the vesicular glutamate transporter 1 (vGluT1; white channel). Panels b-d show the boxed area in panel $\mathbf{c}$ at a higher magnification. Note that dystrophin is concentrated in the intrafusal fiber plasma membrane in areas that are not in contact with the sensory neuron. The blue color represents nuclei stained with 4',6-diamidin-2-phenylindol (DAPI). Panels e-j show the distribution of utrophin (red channel) in the central region of muscle spindles from wildtype (e-g) and from DMD ${ }^{m d x}$ mice (h-j). Anti-vGluT1 antibodies (green channel in panels $\mathbf{e - j}$ ) were used to label the sensory nerve terminal. Panels $\mathbf{d}, \mathbf{g}$ and $\mathbf{j}$ show the merged channels. Utrophin is not detectable in the equatorial region of muscle fibers from wildtype mice (e) but severely upregulated in intrafusal fibers from $\mathrm{DMD}^{\mathrm{mdx}}$ mice (h). Note the absence of utrophin in the contact area between intrafusal fiber and sensory nerve terminal. Asterisks mark corresponding positions in all panels. Panel $\mathbf{k}$ shows a single confocal section of a muscle spindle stained with antibodies against vGluT1 (magenta) and against dystrobrevin (green) to indicate that other components of the DGC have a similar distribution as dystrophin, i.e. are concentrated in areas of the intrafusal fiber that are not in contact with the sensory nerve terminal

spindle number and morphology of intrafusal fibers and their innervation were not changed, but the resting discharge frequency was increased qualitatively and quantitatively similar to $\mathrm{DMD}^{m d x}$ mice [136]. The similarity of the functional changes in $\mathrm{DMD}^{m d x}$ and $d y s f^{/-}$mice suggests a common deficit in both mouse strains, but the molecular mechanism is unknown. The double-mutant mice did not have an aggravated phenotype, suggesting that both mutations coalesce on the same pathway [136].

In contrast to the functional changes in murine model systems for different forms of muscular dystrophy, little if any functional deficits have been observed in muscular dystrophy patients. For example, muscular dystrophy patients perceive passive movements, experience illusory movement induced by muscle tendon vibration, and have proprioceptive-regulated sways in response to vibratory stimulation applied to the neck and ankle muscle tendons [165]. Moreover, reinforcement maneuvers increased the sensitivity of muscle spindle afferents to imposed movements of the ankle in a similar way in DMD patients and in non-affected controls [166]. These findings argue for either preserved proprioceptive functions of muscle spindles or the activation of compensatory mechanisms.

The morphological phenotype in Duchenne muscular dystrophy is rather mild, but are considerably more 
severe in muscle spindles from patients with myotonic dystrophy, where extensive intrafusal fiber splitting was reported $[167,168]$. In addition, sensory endings were undetectable on nuclear bag and nuclear chain fibers. In agreement with these pronounced ultrastructural changes, areflexia has been reported in myotonic dystrophy [169], congenital dystrophies [170] and centronuclear myopathy [171], but not in patients with tibial muscular dystrophy [172].

In summary, studies in humans and mice with muscular dystrophies show various degrees of impairment of muscle spindle function and proprioception. The deficits could alter joint coordination, impair movements and contribute to the instable gait, frequent falls and motor control problems of muscular dystrophy patients. Caregivers and patients should therefore consider an impaired proprioception when developing guidelines and when testing new interventions.

\section{Therapeutic strategies to improve muscle spindle function and proprioception}

The most prevalent symptom of all muscular dystrophy patients is the loss and wasting of skeletal muscle tissue. Therefore, common therapeutic interventions for patients with muscular dystrophy must aim at increasing muscle strength and reducing muscle fatigue and degeneration. A proprioceptive impairment is certainly not the sole cause for the motor control problems in these patients, but the important role of the sensory system controlling motor coordination should not be ignored. In any neuromuscular disease, therapeutic strategies should therefore also aim at restoring/maintaining proprioception and muscle spindle function.

Several ways of improving muscle spindle function in dystrophic patients can be envisioned. The recent identification of the Piezo2 channel as the primary mechanotransduction channel $[6,173]$ might be exploited to develop drugs, which specifically target mechanosensitivity without interfering with extrafusal muscle fiber function or with neuromuscular transmission [174]. These drugs could either directly affect the Piezo2 channel [175] or indirectly, for example via modulatory Gicoupled receptors [176]. However, potential drugs still await clinical trials and approval and side effects due to interference with Piezo2 channels in non-muscle tissues might limit their application [174].

Alternatively, training of the proprioceptive sense is a valuable behavioral therapy for improving impaired motor function and can significantly improve motor control dysfunctions in many neuromuscular disorders and in aging-related proprioceptive decline [177]. Specific proprioceptive training can improve balance control [178], motor learning [177] and walking parameters [179]. A vibratory-based proprioceptive training has been successfully used during rehabilitation to reduce the decline of motor control in subjects with facioscapulohumeral muscular dystrophy [180] and with Parkinson patients [181]. In muscular dystrophy patients, this training slows down the deleterious effects of the gradual decline of motor abilities [166]. Since muscle spindle afferent firing is modified by the emotional context [182], it is conceivable to exploit the emotional situation and vibrational stimuli during physical rehabilitation or training to increase proprioceptive acuity.

Finally, muscle spindle preservation in DMD may be an important factor to exploit new therapeutic approaches for muscular dystrophy patients. For example, the strong upregulation of the utrophin expression in intrafusal fibers from DMD $^{m d x}$ mice [136] might be used to investigate the regulation of the utrophin expression in more detail. Since utrophin can functionally compensate dystrophin deficiency, a better understanding of the signaling cascade underlying utrophin upregulation in $\mathrm{DMD}^{m d x}$ mice might aid in developing strategies for a pharmacological or genetic activation of utrophin expression [183], which might also be applicable to upregulate utrophin expression in extrafusal fibers.

In summary, therapeutic strategies for muscular dystrophy patients should include in addition to strengthening the contractile muscle force, the preservation of muscle spindles and the sensitization of proprioception in order to maintain appropriate motor control and a stable gait and posture.

\section{Abbreviations \\ CNS: Central nervous system; DAPI: 4',6-Diamidin-2-phenylindol; DGC: Dorsal root ganglion; DMD: Duchenne muscular dystrophy; DP: Dynamic peak; ErbB2: Erb-b2 receptor tyrosine kinase 2; Egr3: Early growth response protein 3; Etv1: ETS variant transcription factor 1; Ig-Nrg1: Immunoglobulin form of neuregulin-1; MuSK: Muscle-specific kinase; NT3: Neurotrophin-3; P: Postnatal day; RD: Resting discharge; Runx3: Runt-related transcription factor 3; SR: Static response; TrkC receptor: Tropomyosin receptor kinase $\mathrm{C}$ receptor; vGluT1: Vesicular glutamate transporter 1}

\section{Acknowledgements}

The author would like to thank Edith Ribot-Ciscar, Benedikt Schoser, Bob Banks and Guy Bewick for critically reading and improving the manuscript. The contribution of Sarah Rossmanith and Yina Zhang to Figs. 3 and 4 is gratefully acknowledged.

\section{Authors' contributions}

All authors participated in the design and coordination of the text and helped to draft this review. All authors prepared, read and approved the final manuscript.

\section{Funding}

Research in the lab of the first author is supported by the German Research Foundation (DFG; Kr1039/16), the Friedrich-Baur-Society, the German Society for Muscle Disease (DGM), the German Academic Exchange Service (DAAD), and the Munich Center for Neurosciences-Brain \& Mind.

Availability of data and materials

Not applicable.

Ethics approval and consent to participate Not applicable. 


\section{Competing interests}

The authors have no conflict of interest to report.

Received: 10 November 2020 Accepted: 20 December 2020 Published online: 07 January 2021

\section{References}

1. Sherrington CS. On the proprio-ceptive system, especially in its reflex aspect. Brain. 1907:29(4):467-82

2. Dietz V. Proprioception and locomotor disorders. Nature Rev Neurosci. 2002; 3(10):781-90.

3. Kiehn O. Decoding the organization of spinal circuits that control locomotion. Nature Rev Neurosci. 2016:17(4):224-38.

4. Kröger S. Proprioception 2.0: novel functions for muscle spindles. Curr Opin Neurol. 2018;31(5):592-8.

5. Cole JD, Sedgwick EM. The perceptions of force and of movement in a man without large myelinated sensory afferents below the neck. J Physiol. 1992; 449:503-15.

6. Chesler AT, Szczot M, Bharucha-Goebel D, Ceko M, Donkervoort S, Laubacher $\mathrm{C}$, et al. The role of PIEZO2 in human mechanosensation. New Eng J Med. 2016;375(14):1355-64.

7. Delle Vedove A, Storbeck M, Heller R, Holker I, Hebbar M, Shukla A, et al. Biallelic loss of proprioception-related PIEZO2 causes muscular atrophy with perinatal respiratory distress, arthrogryposis, and scoliosis. Am J Hum Genet. 2016;99(6):1406-8.

8. Haliloglu G, Becker K, Temucin C, Talim B, Kucuksahin N, Pergande M, et al. Recessive PIEZO2 stop mutation causes distal arthrogryposis with distal muscle weakness, scoliosis and proprioception defects. J Hum Genet. 2017; 62(4):497-501.

9. Mahmud AA, Nahid NA, Nassif C, Sayeed MS, Ahmed MU, Parveen M, et al. Loss of the proprioception and touch sensation channel PIEZO2 in siblings with a progressive form of contractures. Clin Genet. 2017;91(3):470-5.

10. Smith LJ, Norcliffe-Kaufmann L, Palma JA, Kaufmann H, Macefield VG. Impaired sensorimotor control of the hand in congenital absence of functional muscle spindles. J Neurophysiol. 2018;120(6):2788-95.

11. Masingue M, Faure J, Sole G, Stojkovic T, Leonard-Louis S. A novel nonsense PIEZO2 mutation in a family with scoliosis and proprioceptive defect. Neuromusc Disord. 2019;29(1):75-9.

12. Behunova J, Gerykova Bujalkova M, Gras G, Taylor T, Ihm U, Kircher S, et al. Distal arthrogryposis with impaired proprioception and touch: description of an early phenotype in a boy with compound heterozygosity of PIEZO2 mutations and review of the literature. Mol Syndromol. 2019;9(6):287-94.

13. Blecher R, Heinemann-Yerushalmi L, Assaraf E, Konstantin N, Chapman JR, Cope TC, Bewick GS, Banks RW, Zelzer E. New functions for the proprioceptive system in skeletal biology. Phil Trans R Soc B. 2018;373: 20170327. http://dx.doi.org/10.1098/rstb.2017.0327.

14. Blecher R, Krief S, Galili T, Assaraf E, Stern T, Anekstein Y, et al. The proprioceptive system regulates morphologic restoration of fractured bones. Cell Rep. 2017;20(8):1775-83.

15. Blecher R, Krief S, Galili T, Biton IE, Stern T, Assaraf E, et al. The proprioceptive system masterminds spinal alignment: insight into the mechanism of scoliosis. Dev Cell. 2017:42(4):388-99 e3.

16. Takeoka A, Vollenweider I, Courtine G, Arber S. Muscle spindle feedback directs locomotor recovery and circuit reorganization after spinal cord injury. Cell. 2014;159(7):1626-39.

17. Takeoka A, Arber S. Functional local proprioceptive feedback circuits initiate and maintain locomotor recovery after spinal cord injury. Cell Rep. 2019; 27(1):71-85 e3.

18. Assaraf E, Blecher R, Heinemann-Yerushalmi L, Krief $S$, Carmel Vinestock $R$, Biton IE, et al. Piezo2 expressed in proprioceptive neurons is essential for skeletal integrity. Nature Communicat. 2020;11(1):3168.

19. Matthews PB. Where Anatomy led, Physiology followed: a survey of our developing understanding of the muscle spindle, what it does and how it works. J Anat. 2015:227(2):104-14.

20. Proske U, Gandevia SC. The proprioceptive senses: their roles in signaling body shape, body position and movement, and muscle force. Physiol Rev. 2012;92(4):1651-97.

21. Banks RW, Barker D. In: Engel AG, Franzini-Armstrong C, editors. The muscle spindle. Myology (McGraw-Hill). 3rd ed; 2004. p. 489-509.

22. Cobo JL, Abbate F, de Vicente JC, Cobo J, Vega JA. Searching for proprioceptors in human facial muscles. Neurosci Lett. 2017;640:1-5.
23. Blumer R, Lukas JR, Aigner M, Bittner R, Baumgartner I, Mayr R. Fine structural analysis of extraocular muscle spindles of a two-year-old human infant. Invest Ophthalmol Vis Sci. 1999;40(1):55-64.

24. Buttner-Ennever JA, Konakci KZ, Blumer R. Sensory control of extraocular muscles. Prog Brain Res. 2006;151:81-93.

25. Lienbacher K, Mustari M, Hess B, Buttner-Ennever J, Horn AK. Is there any sense in the palisade endings of eye muscles? Ann N Y Acad Sci. 2011;1233: $1-7$.

26. Wilkinson KA, Kloefkorn HE, Hochman S. Characterization of muscle spindle afferents in the adult mouse using an in vitro muscle-nerve preparation. PloS one. 2012;7(6):e39140.

27. Kennedy WR. Innervation of normal human muscle spindles. Neurology. 1970:20(5):463-75.

28. Lionikas A, Smith CJ, Smith TL, Bunger L, Banks RW, Bewick GS. Analyses of muscle spindles in the soleus of six inbred mouse strains. J Anat. 2013;223(3):289-96.

29. Macefield VG, Knellwolf TP. Functional properties of human muscle spindles. J Neurophysiol. 2018;120(2):452-67.

30. Osterlund C, Liu JX, Thornell LE, Eriksson PO. Muscle spindle composition and distribution in human young masseter and biceps brachii muscles reveal early growth and maturation. Anat Rec. 2011;294(4):683-93.

31. Kuffler SW, Hunt CC, Quilliam JP. Function of medullated small-nerve fibers in mammalian ventral roots; efferent muscle spindle innervation. J Neurophysiol. 1951;14(1):29-54.

32. Edman KA, Radzyukevich T, Kronborg B. Contractile properties of isolated muscle spindles of the frog. Journal Physiol. 2002;541(Pt 3):905-16.

33. Boyd IA. The structure and innervation of the nuclear bag muscle fibre system and the nuclear chain muscle fibre system in mammalian muscle spindles. Phil Trans Royal Soc Series B, Biol Sci. 1962;245:81-136.

34. Banks RW. The innervation of the muscle spindle: a personal history. J Anat. 2015;227(2):115-35

35. Gerwin L, Haupt C, Wilkinson KA, Kröger S. Acetylcholine receptors in the equatorial region of intrafusal muscle fibres modulate mouse muscle spindle sensitivity. J Physiol. 2019;597(7):1993-2006.

36. Oliver KM, Florez-Paz DM, Badea TC, Mentis GZ, Menon V, de Nooij JC. Molecular development of muscle spindle and Golgi tendon organ sensory afferents revealed by single proprioceptor transcriptome analysis. bioRxiv. 2020. https://doi.org/10.1101/2020.04.03.023986.

37. Schröder JM, Bodden $\mathrm{H}$, Hamacher A, Verres C. Scanning electron microscopy of teased intrafusal muscle fibers from rat muscle spindles. Muscle Nerve. 1989;12(3):221-32.

38. Sonner MJ, Walters MC, Ladle DR. Analysis of proprioceptive sensory innervation of the mouse soleus: a whole-mount muscle approach. PloS one. 2017;12(1):e0170751.

39. Kennedy WR, Webster HF, Yoon KS. Human muscle spindles: fine structure of the primary sensory ending. J Neurocytol. 1975:4(6):675-95.

40. Banks RW, Hulliger M, Saed HH, Stacey MJ. A comparative analysis of the encapsulated end-organs of mammalian skeletal muscles and of their sensory nerve endings. J Anat. 2009;214(6):859-87.

41. Lee J, Friese A, Mielich M, Sigrist M, Arber S. Scaling proprioceptor gene transcription by retrograde NT3 signaling. PloS one. 2012;7(9):e45551.

42. Usoskin D, Furlan A, Islam S, Abdo H, Lonnerberg P, Lou D, et al. Unbiased classification of sensory neuron types by large-scale single-cell RNA sequencing. Nat Neurosci. 2015;18(1):145-53.

43. De-Doncker L, Picquet F, Petit J, Falempin M. Characterization of spindle afferents in rat soleus muscle using ramp-and-hold and sinusoidal stretches. J Neurophysiol. 2003;89(1):442-9.

44. Johnson MI, Ovalle WK. A comparative study of muscle spindles in slow and fast neonatal muscles of normal and dystrophic mice. Am J Anat. 1986; 175(4):413-27.

45. Bewick GS, Banks RW. Mechanotransduction in the muscle spindle. Pflugers Archiv: Eur J Physiol. 2015:467(1):175-90.

46. Franco JA, Kloefkorn HE, Hochman S, Wilkinson KA. An in vitro adult mouse muscle-nerve preparation for studying the firing properties of muscle afferents. J Vis Exp. 2014;91:51948.

47. Banks RW. The motor innervation of mammalian muscle-spindles. Prog Neurobiol. 1994:43(4-5):323-62.

48. Manuel M, Zytnicki D. Alpha, beta and gamma motoneurons: functional diversity in the motor system's final pathway. J Integr Neurosci. 2011;10(3):243-76.

49. Zhang Y, Lin S, Karakatsani A, Rüegg MA, Kröger S. Differential regulation of AChR clustering in the polar and equatorial region of murine muscle spindles. Eur J Neurosci. 2015;41(1):69-78. 
50. Proske U. The mammalian muscle spindle. News Physiol Sci. 1997;12:37-42.

51. Przedpelska-Ober E. The development of muscle spindles in human fetuses. Anat Anz. 1982;152(4):371-80.

52. Mavrinskaya LF. Development of muscle spindles in man. Neurosci Translat. 1968;2:529-35

53. Deriu F, Tedde Piras A, Montella A. The early development of muscle spindle in human foetus. Ital J Anat Embryol. 1996;101(3):163-72.

54. Kozeka K, Ontell M. The three-dimensional cytoarchitecture of developing murine muscle spindles. Deve Biol. 1981;87(1):133-47.

55. Zelena J. Nerves and mechanoreceptors - the role of innervation in the development and maintenance of mammalian mechanoreceptors. New York: Chapman and Hall; 1994. p. 38-137.

56. Kucera J, Walro JM. Origin of intrafusal fibers from a subset of primary myotubes in the rat. Anat Embryol. 1995;192(2):149-58.

57. Barbet JP, Thornell LE, Butler-Browne GS. Immunocytochemical characterisation of two generations of fibers during the development of the human quadriceps muscle. Mech Dev. 1991;35(1):3-11.

58. Landon DN. The fine structure of the equatorial regions of developing muscle spindles in the rat. J Neurocytol. 1972;1(2):189-210.

59. Kucera J, Walro JM. Sequences of intrafusal fiber formation are muscledependent in rat hindlimbs. Anat Embryol. 1994;190(3):273-86.

60. Kucera J, Walro JM, Reichler J. Motor and sensory innervation of muscle spindles in the neonatal rat. Anat Embryol. 1988:177:427-36.

61. Kucera J, Walro JM, Reichler J. Role of nerve and muscle factors in the development of rat muscle spindles. Am J Anat. 1989;186:144-60.

62. Maeda N, Osawa K, Masuda T, Hakeda Y, Kumegawa M. Postnatal development of the anulospiral endings of la fibers in muscle spindles of mice. Acta Anat. 1985;124(1-2):42-6.

63. Osawa K, Maeda N, Sato M, Kawasaki T, Masuda T, Yamamoto Y, et al. Postnatal development of the annulospiral endings of la fibers in muscle spindles of the mouse temporal muscle. Anat Anz. 1988;167(4):253-7.

64. Holst-Wolf JM, Yeh IL, Konczak J. Development of proprioceptive acuity in typically developing children: normative data on forearm position sense. Front Hum Neurosci. 2016;10:436

65. Vejsada R, Hnik P, Payne R, Ujec E, Palecek J. The postnatal functional development of muscle stretch receptors in the rat. Somatosens Res. 1985;2(3):205-22.

66. Kucera J, Walro JM, Reichler J. Differential effects of neonatal denervation on intrafusal muscle fibers in the rat. Anat Embryol. 1993:187(4):397-408.

67. Kucera J, Walro JM. Postnatal maturation of spindles in deafferented rat soleus muscles. Anat Embryol. 1987;176(4):449-61.

68. Zelena J. The role of sensory innervation in the development of mechanoreceptors. Prog Brain Res. 1976;43:59-64.

69. Hippenmeyer S, Shneider NA, Birchmeier C, Burden SJ, Jessell TM, Arber S. A role for neuregulin1 signaling in muscle spindle differentiation. Neuron. 2002;36(6):1035-49.

70. Cheret C, Willem M, Fricker FR, Wende H, Wulf-Goldenberg A, Tahirovic S, et al. Bace1 and neuregulin-1 cooperate to control formation and maintenance of muscle spindles. EMBO J. 2013;32(14):2015-28.

71. Andrechek ER, Hardy WR, Girgis-Gabardo AA, Perry RL, Butler R, Graham FL, et al. ErbB2 is required for muscle spindle and myoblast cell survival. Mol Cell Biol. 2002;22(13):4714-22.

72. Leu M, Bellmunt E, Schwander M, Farinas I, Brenner HR, Muller U. Erbb2 regulates neuromuscular synapse formation and is essential for muscle spindle development. Development. 2003;130(11):2291-301.

73. Tourtellotte WG, Keller-Peck C, Milbrandt J, Kucera J. The transcription factor Egr3 modulates sensory axon-myotube interactions during muscle spindle morphogenesis. Dev Biol. 2001;232(2):388-99.

74. Oliveira Fernandes M, Tourtellotte WG. Egr3-dependent muscle spindle stretch receptor intrafusal muscle fiber differentiation and fusimotor innervation homeostasis. J Neurosci. 2015;35(14):5566-78.

75. Tourtellotte WG, Milbrandt J. Sensory ataxia and muscle spindle agenesis in mice lacking the transcription factor Egr3. Nat Genet. 1998;20(1):87-91.

76. Arber S, Ladle DR, Lin JH, Frank E, Jessell TM. ETS gene Er81 controls the formation of functional connections between group la sensory afferents and motor neurons. Cell. 2000;101(5):485-98.

77. Park SY, Jang SY, Shin YK, Yoon BA, Lee HJ, Park HT. Grb2-associated binder1 is required for extrafusal and intrafusal muscle fiber development. Neuroreport. 2017;28(10):604-9.

78. Albert Y, Whitehead J, Eldredge L, Carter J, Gao X, Tourtellotte WG. Transcriptional regulation of myotube fate specification and intrafusal muscle fiber morphogenesis. J Cell Biol. 2005;169(2):257-68.
79. Smeyne RJ, Klein R, Schnapp A, Long LK, Bryant S, Lewin A, et al. Severe sensory and sympathetic neuropathies in mice carrying a disrupted Trk/NGF receptor gene. Nature. 1994;368(6468):246-9.

80. Ernfors P, Lee KF, Kucera J, Jaenisch R. Lack of neurotrophin-3 leads to deficiencies in the peripheral nervous system and loss of limb proprioceptive afferents. Cell. 1994;77(4):503-12.

81. Klein R, Silos-Santiago I, Smeyne RJ, Lira SA, Brambilla R, Bryant S, et al. Disruption of the neurotrophin-3 receptor gene trkC eliminates la muscle afferents and results in abnormal movements. Nature. 1994;368(6468):24951.

82. Kucera J, Fan G, Walro J, Copray S, Tessarollo L, Jaenisch R. Neurotrophin-3 and trkC in muscle are non-essential for the development of mouse muscle spindles. Neuroreport. 1998:9(5):905-9.

83. Wright DE, Zhou L, Kucera J, Snider WD. Introduction of a neurotrophin-3 transgene into muscle selectively rescues proprioceptive neurons in mice lacking endogenous neurotrophin-3. Neuron. 1997;19(3):503-17.

84. Taylor MD, Vancura R, Patterson CL, Williams JM, Riekhof JT, Wright DE. Postnatal regulation of limb proprioception by muscle-derived neurotrophin-3. J Comp Neurol. 2001;432(2):244-58.

85. Taylor MD, Holdeman AS, Weltmer SG, Ryals JM, Wright DE. Modulation of muscle spindle innervation by neurotrophin-3 following nerve injury. Exp Neurol. 2005;191(1):211-22.

86. Patel TD, Kramer I, Kucera J, Niederkofler V, Jessell TM, Arber S, et al. Peripheral NT3 signaling is required for ETS protein expression and central patterning of proprioceptive sensory afferents. Neuron. 2003;38(3):403-16.

87. de Nooij JC, Doobar S, Jessell TM. Etv1 inactivation reveals proprioceptor subclasses that reflect the level of NT3 expression in muscle targets. Neuron. 2013;77(6):1055-68.

88. Appel E, Weissmann S, Salzberg Y, Orlovsky K, Negreanu V, Tsoory M, et al. An ensemble of regulatory elements controls Runx3 spatiotemporal expression in subsets of dorsal root ganglia proprioceptive neurons. Genes Dev. 2016;30(23):2607-22.

89. Levanon D, Bettoun D, Harris-Cerruti C, Woolf E, Negreanu V, Eilam R, et al. The Runx3 transcription factor regulates development and survival of TrkC dorsal root ganglia neurons. EMBO J. 2002;21(13):3454-63.

90. Verschueren SM, Brumagne S, Swinnen SP, Cordo PJ. The effect of aging on dynamic position sense at the ankle. Behav Brain Res. 2002;136(2):593-603.

91. Landelle C, El Ahmadi A, Kavounoudias A. Age-related impairment of hand movement perception based on muscle proprioception and touch. Neuroscience. 2018;381:91-104.

92. Swash M, Fox KP. The effect of age on human skeletal muscle. Studies of the morphology and innervation of muscle spindles. J Neurol Sci. 1972; 16(4):417-32.

93. Liu JX, Eriksson PO, Thornell LE, Pedrosa-Domellof F. Fiber content and myosin heavy chain composition of muscle spindles in aged human biceps brachii. J Histochem Cytochem. 2005;53(4):445-54.

94. Kim GH, Suzuki S, Kanda K. Age-related physiological and morphological changes of muscle spindles in rats. J Physiol. 2007;582(Pt 2):525-38.

95. Desaki J, Nishida N. Novel muscle spindles containing muscle fibers devoid of sensory innervation in the extensor digitorum longus muscle of aged rats. J Electron Microsc. 2008;57(2):77-82.

96. Vaughan SK, Stanley OL, Valdez G. Impact of aging on proprioceptive sensory neurons and intrafusal muscle fibers in mice. J Gerontol A, Biol Sci Med Sci. 2017;72(6):771-9.

97. Conte A, Khan N, Defazio G, Rothwell JC, Berardelli A. Pathophysiology of somatosensory abnormalities in Parkinson disease. Nat Rev Neurol. 2013; 9(12):687-97.

98. Abbruzzese G, Berardelli A. Sensorimotor integration in movement disorders. Movement Disord. 2003;18(3):231-40.

99. Cameron MH, Horak FB, Herndon RR, Bourdette D. Imbalance in multiple sclerosis: a result of slowed spinal somatosensory conduction. Somatosens Mot Res. 2008:25(2):113-22.

100. Villalon E, Jones MR, Sibigtroth C, Zino SJ, Dale JM, Landayan DS, et al. Muscle spindle alterations precede onset of sensorimotor deficits in Charcot-Marie-Tooth type 2E. Genes Brain Behavior. 2017;16(2):260-70.

101. Vincent JA, Nardelli P, Gabriel HM, Deardorff AS, Cope TC. Complex impairment of IA muscle proprioceptors following traumatic or neurotoxic injury. J Anat. 2015;227(2):221-30.

102. Mentis GZ, Blivis D, Liu W, Drobac E, Crowder ME, Kong L, et al. Early functional impairment of sensory-motor connectivity in a mouse model of spinal muscular atrophy. Neuron. 2011;69(3):453-67. 
103. van Deursen RW, Sanchez MM, Ulbrecht JS, Cavanagh PR. The role of muscle spindles in ankle movement perception in human subjects with diabetic neuropathy. Exp Brain Res. 1998;120(1):1-8.

104. Muller KA, Ryals JM, Feldman EL, Wright DE. Abnormal muscle spindle innervation and large-fiber neuropathy in diabetic mice. Diabetes. 2008; 57(6):1693-701.

105. Swash M, Fox KP. The pathology of the muscle spindle in myasthenia gravis. J Neurol Sci. 1975;26(1):39-47.

106. Cazzato G, Walton JN. The pathology of the muscle spindle. A study of biopsy material in various muscular and neuromuscular diseases. J Neurol Sci. 1968;7(1):15-70.

107. Vaughan SK, Kemp Z, Hatzipetros T, Vieira F, Valdez G. Degeneration of proprioceptive sensory nerve endings in mice harboring amyotrophic lateral sclerosis-causing mutations. J Comp Neurol. 2015;523(17):2477-94.

108. Sangari S, Iglesias C, El Mendili MM, Benali H, Pradat PF, Marchand-Pauvert $\mathrm{V}$. Impairment of sensory-motor integration at spinal level in amyotrophic lateral sclerosis. Clin Neurophysiol. 2016;127(4):1968-77.

109. Sabado J, Casanovas A, Tarabal O, Hereu M, Piedrafita L, Caldero J, et al. Accumulation of misfolded SOD1 in dorsal root ganglion degenerating proprioceptive sensory neurons of transgenic mice with amyotrophic lateral sclerosis. Biomed Res Int. 2014;2014:852163.

110. Seki S, Yamamoto T, Quinn K, Spigelman I, Pantazis A, Olcese R, et al. Circuit-specific early impairment of proprioceptive sensory neurons in the SOD1(G93A) Mouse Model for ALS. J Neurosci. 2019;39(44):8798-815.

111. Powis RA, Gillingwater TH. Selective loss of alpha motor neurons with sparing of gamma motor neurons and spinal cord cholinergic neurons in a mouse model of spinal muscular atrophy. J Anat. 2016;228(3):443-51.

112. Lalancette-Hebert M, Sharma A, Lyashchenko AK, Shneider NA. Gamma motor neurons survive and exacerbate alpha motor neuron degeneration in ALS. Proc Natl Acad Sci U S A. 2016:113(51):E8316-E25.

113. Falgairolle M, O'Donovan MJ. Motoneuronal spinal circuits in degenerative motoneuron disease. Front Mol Neurosci. 2020;13:74

114. Mercuri E, Muntoni F. Muscular dystrophies. Lancet. 2013;381(9869):845-60.

115. Campbell KP, Kahl SD. Association of dystrophin and an integral membrane glycoprotein. Nature. 1989;338(6212):259-62.

116. Gao QQ, McNally EM. The dystrophin complex: structure, function, and implications for therapy. Compr Physiol. 2015;5(3):1223-39.

117. Mah JK, Korngut L, Dykeman J, Day L, Pringsheim T, Jette N. A systematic review and meta-analysis on the epidemiology of Duchenne and Becker muscular dystrophy. Neuromusc Disord. 2014;24(6):482-91.

118. Blake DJ, Kröger S. The neurobiology of Duchenne muscular dystrophy: learning lessons from muscle? Trends Neurosci. 2000;23(3):92-9.

119. Ervasti JM. Dystrophin, its interactions with other proteins, and implications for muscular dystrophy. Biochimica Biophys Acta. 2007:1772(2):108-17.

120. Waite A, Brown SC, Blake DJ. The dystrophin-glycoprotein complex in brain development and disease. Trends Neurosci. 2012;35(8):487-96.

121. Goldstein JA, McNally EM. Mechanisms of muscle weakness in muscular dystrophy. J Gen Physiol. 2010;136(1):29-34.

122. Le Rumeur E, Winder SJ, Hubert JF. Dystrophin: more than just the sum of its parts. Biochim Biophys Acta. 2010;1804(9):1713-22.

123. Wallace GQ, McNally EM. Mechanisms of muscle degeneration, regeneration, and repair in the muscular dystrophies. Annu Rev Physiol. 2009;71:37-57

124. Mosqueira M, Zeiger U, Forderer M, Brinkmeier H, Fink RH. Cardiac and respiratory dysfunction in Duchenne muscular dystrophy and the role of second messengers. Med Res Rev. 2013;33(5):1174-213.

125. Hsu JD, Furumasu J. Gait and posture changes in the Duchenne muscular dystrophy child. Clin Orthopaed Rel Res. 1993;288:122-5.

126. Mahjneh I, Marconi G, Bushby K, Anderson LV, Tolvanen-Mahjneh H, Somer H. Dysferlinopathy (LGMD2B): a 23-year follow-up study of 10 patients homozygous for the same frameshifting dysferlin mutations. Neuromuscul Disord. 2001;11(1):20-6.

127. Pradhan S, Ghosh D, Srivastava NK, Kumar A, Mittal B, Pandey CM, et al. Prednisolone in Duchenne muscular dystrophy with imminent loss of ambulation. J Neurol. 2006;253(10):1309-16.

128. Troise D, Yoneyama S, Resende MB, Reed U, Xavier GF, Hasue R. The influence of visual and tactile perception on hand control in children with Duchenne muscular dystrophy. Dev Med Child Neurol. 2014;56(9):882-7.

129. Kararizou EG, Manta P, Kalfakis N, Gkiatas KA, Vassilopoulos D. Morphologic and morphometrical study of the muscle spindle in muscular dystrophy. Analyt Quantitat Cytol Hstol. 2007;29(3):148-52.
130. Swash M, Fox KP. The pathology of the muscle spindle in Duchenne muscular dystrophy. J Neurol Sci. 1976;29(1):17-32.

131. Skuk D, Goulet M, Tremblay JP. Preservation of muscle spindles in a 27-yearold Duchenne muscular dystrophy patient: importance for regenerative medicine strategies. Muscle Nerve. 2010;41(5):729-30.

132. Ovalle WK, Dow PR. Alterations in muscle spindle morphology in advanced stages of murine muscular dystrophy. Anat Rec. 1986;216(2):111-26.

133. Bulfield G, Siller WG, Wight PA, Moore KJ. X chromosome-linked muscular dystrophy (mdx) in the mouse. Proc Natl Acad Sci USA. 1984;81(4):1189-92.

134. Willmann R, Possekel S, Dubach-Powell J, Meier T, Ruegg MA. Mammalian animal models for Duchenne muscular dystrophy. Neuromuscul Disord. 2009;19(4):241-9.

135. Yellin $\mathrm{H}$. Spindle induction and differentiation in murine dystrophy. Experientia. 1974;30(3):286-7.

136. Gerwin L, Rossmanith S, Haupt C, Schultheiss J, Brinkmeier H, Bittner RE, et al. Impaired muscle spindle function in murine models of muscular dystrophy. J Physiol. 2020;598(8):1591-609.

137. Khurana TS, Prendergast RA, Alameddine HS, Tome FM, Fardeau M, Arahata $\mathrm{K}$, et al. Absence of extraocular muscle pathology in Duchenne's muscular dystrophy: role for calcium homeostasis in extraocular muscle sparing. J Exp Med. 1995:182(2):467-75.

138. Karpati G, Carpenter S. Small-caliber skeletal muscle fibers do not suffer deleterious consequences of dystrophic gene expression. Am J Med Genet. 1986;25(4):653-8.

139. Nahirney PC, Ovalle WK. Distribution of dystrophin and neurofilament protein in muscle spindles of normal and Mdx-dystrophic mice: an immunocytochemical study. Anat Rec. 1993;235(4):501-10.

140. Tinsley JM, Blake DJ, Roche A, Fairbrother U, Riss J, Byth BC, et al. Primary structure of dystrophin-related protein. Nature. 1992;360:591-3.

141. Khurana TS, Watkins SC, Chafey P, Chelly J, Tome FM, Fardeau M, et al. Immunolocalization and developmental expression of dystrophin related protein in skeletal muscle. Neuromuscul Disord. 1991;1(3):185-94.

142. Lin S, Gaschen F, Burgunder JM. Utrophin is a regeneration-associated protein transiently present at the sarcolemma of regenerating skeletalmuscle fibers in dystrophin-deficient hypertrophic feline muscular dystrophy. J Neuropathol Exp Neurol. 1998;57:780-90.

143. Ohlendieck K, Ervasti JM, Matsumura K, Kahl SD, Leveille CJ, Campbell KP. Dystrophin-related protein is localized to neuromuscular junctions of adult skeletal muscle. Neuron. 1991;7(3):499-508.

144. Schofield J, Houzelstein D, Davies K, Buckingham M, Edwards YH. Expression of the dystrophin-related protein (utrophin) gene during mouse embryogenesis. Dev Dyn. 1993;198(4):254-64.

145. Nguyen TM, Ellis JM, Love DR, Davies KE, Gatter KC, Dickson G, et al. Localization of the DMDL gene-encoded dystrophin-related protein using a panel of nineteen monoclonal antibodies: presence at neuromuscular junctions, in the sarcolemma of dystrophic skeletal muscle, in vascular and other smooth muscles, and in proliferating brain cell lines. J Cell Biol. 1991; 115(6):1695-700

146. Bewick GS, Nicholson LVB, Young C, O'Donnell E, Slater CR. Different distributions of dystrophin and related proteins at nerve-muscle junctions. Neuroreport. 1992;3:857-60.

147. Pons F, Nicholson LV, Robert A, Voit T, Leger JJ. Dystrophin and dystrophinrelated protein (utrophin) distribution in normal and dystrophin-deficient skeletal muscles. Neuromuscul Disord. 1993;3(5-6):507-14.

148. Hirst RC, McCullagh KJ, Davies KE. Utrophin upregulation in Duchenne muscular dystrophy. Acta Myologica. 2005;24(3):209-16.

149. Tinsley J, Deconinck N, Fisher R, Kahn D, Phelps S, Gillis JM, et al. Expression of full-length utrophin prevents muscular- dystrophy in $m d x$ mice. Nat Med. 1998:4:1441-4.

150. Gilbert R, Nalbantoglu J, Petrof BJ, Ebihara S, Guibinga GH, Tinsley JM, et al. Adenovirus-mediated utrophin gene transfer mitigates the dystrophic phenotype of mdx mouse muscles. Hum Gene Ther. 1999;10(8):1299-310.

151. Tinsley JM, Fairclough RJ, Storer R, Wilkes FJ, Potter AC, Squire SE, et al. Daily treatment with SMTC1100, a novel small molecule utrophin upregulator, dramatically reduces the dystrophic symptoms in the $\mathrm{mdx}$ mouse. PloS one. 2011;6(5):e19189.

152. Guiraud S, Edwards B, Babbs A, Squire SE, Berg A, Moir L, et al. The potential of utrophin and dystrophin combination therapies for Duchenne muscular dystrophy. Hum Mol Genet. 2019;28(13):2189-200.

153. Davies KE, Chamberlain JS. Surrogate gene therapy for muscular dystrophy. Nat Med. 2019;25(10):1473-4. 
154. Bittner RE, Anderson LVB, Burkhardt E, Bashir R, Vafiadaki E, Ivanova S, et al Dysferlin deletion in SJL mice (SJL-Dysf) defines a natural model for limb girdle muscular dystrophy 2B. Nat Genet. 1999;23(2):141-2.

155. Hornsey MA, Laval SH, Barresi R, Lochmüller H, Bushby K. Muscular dystrophy in dysferlin-deficient mouse models. Neuromuscul Disord. 2013; 23(5):377-87.

156. Cardenas AM, Gonzalez-Jamett AM, Cea LA, Bevilacqua JA, Caviedes P. Dysferlin function in skeletal muscle: possible pathological mechanisms and therapeutical targets in dysferlinopathies. Exp Neurol. 2016;283(Pt A):246-54.

157. Bashir R, Britton S, Strachan T, Keers S, Vafiadaki E, Lako M, et al. A gene related to Caenorhabditis elegans spermatogenesis factor fer- 1 is mutated in limb-girdle muscular dystrophy type 2B. Nat Genet. 1998;20(1):37-42.

158. Liu J, Aoki M, Illa I, Wu C, Fardeau M, Angelini C, et al. Dysferlin, a novel skeletal muscle gene, is mutated in Miyoshi myopathy and limb girdle muscular dystrophy. Nat Genet. 1998;20(1):31-6.

159. Aoki M, Liu J, Richard I, Bashir R, Britton S, Keers SM, et al. Genomic organization of the dysferlin gene and novel mutations in Miyoshi myopathy. Neurology. 2001;57(2):271-8.

160. Anderson LV, Davison K, Moss JA, Young C, Cullen MJ, Walsh J, et al. Dysferlin is a plasma membrane protein and is expressed early in human development. Hum Mol Genet. 1999;8(5):855-61.

161. Barthelemy F, Defour A, Levy N, Krahn M, Bartoli M. Muscle cells fix breaches by orchestrating a membrane repair ballet. J Neuromuscul Dis. 2018;5(1):218 .

162. Matsuda C, Kiyosue K, Nishino I, Goto Y, Hayashi YK. Dysferlinopathy fibroblasts are defective in plasma membrane repair. PLoS currents. 2015;7. https://doi.org/10.1371/currents.md.5865add2d766f39a0e0411d38a7ba09c.

163. Han R, Campbell KP. Dysferlin and muscle membrane repair. Curr Opin Cell Biol. 2007;19(4):409-16.

164. Kerr JP, Ziman AP, Mueller AL, Muriel JM, Kleinhans-Welte E, Gumerson JD, et al. Dysferlin stabilizes stress-induced $\mathrm{Ca} 2+$ signaling in the transverse tubule membrane. Proc Natl Acad Sci U S A. 2013;110(51):20831-6.

165. Ribot-Ciscar E, Trefouret S, Aimonetti JM, Attarian S, Pouget J, Roll JP. Is muscle spindle proprioceptive function spared in muscular dystrophies? A muscle tendon vibration study. Muscle Nerve. 2004;29(6):861-6.

166. Aimonetti JM, Ribot-Ciscar E, Rossi-Durand C, Attarian S, Pouget J, Roll JP. Functional sparing of intrafusal muscle fibers in muscular dystrophies. Muscle Nerve. 2005;32(1):88-94.

167. Maynard JA, Cooper RR, lonaescu W. An ultrastructure investigation of intrafusal muscle fibers in myotonic dystrophy. Virchows Arch. 1977;373(1): $1-13$.

168. Swash M, Fox KP. Abnormal intrafusal muscle fibres in myotonic dystrophy: a study using serial sections. J Neurol Neurosurg Psychiatry. 1975;38(1):91-9.

169. Messina C, Tonali P, Scoppetta C. The lack of deep reflexes in myotonic dystrophy. J Neurol Sci. 1976;30(2-3):303-11.

170. Pouget J, Gastaut JL, Pellissier JF, Cros D, Serratrice G. Tendon areflexia in congenital myopathies accompanied by atrophy of type I fibers. Electrophysiologic study. Rev Electroencephalogr Neurophysiol Clin. 1984; 13(4):323-8.

171. Zanoteli E, Oliveira AS, Schmidt B, Gabbai AA. Centronuclear myopathy: clinical aspects of ten Brazilian patients with childhood onset. J Neurol Sci. 1998;158(1):76-82.

172. Udd B, Haravuori H, Kalimo H, Partanen J, Pulkkinen L, Paetau A, et al. Tibial muscular dystrophy - from clinical description to linkage on chromosome 2q31. Neuromuscul Disord. 1998;8(5):327-32

173. Woo SH, Lukacs V, de Nooij JC, Zaytseva D, Criddle CR, Francisco A, et al. Piezo2 is the principal mechanotransduction channel for proprioception. Nat Neurosci. 2015;18(12):1756-62.

174. Xiao B. Levering mechanically activated Piezo channels for potential pharmacological intervention. Annu Rev Pharmacol Toxicol. 2020;60:195218.

175. Alcaino C, Knutson K, Gottlieb PA, Farrugia G, Beyder A. Mechanosensitive ion channel Piezo2 is inhibited by D-GsMTx4. Channels. 2017;11(3):245-53.

176. Del Rosario JS, Yudin Y, Su S, Hartle CM, Mirshahi T, Rohacs T. Gi-coupled receptor activation potentiates Piezo2 currents via Gbetagamma. EMBO Rep. 2020;21(5):e49124.

177. Aman JE, Elangovan N, Yeh IL, Konczak J. The effectiveness of proprioceptive training for improving motor function: a systematic review. Front Hum Neurosci. 2014;8:1075.
178. Tibone JE, Fechter J, Kao JT. Evaluation of a proprioception pathway in patients with stable and unstable shoulders with somatosensory cortical evoked potentials. J Shoulder Elbow Surg. 1997;6(5):440-3.

179. Yong MS, Lee YS. Effect of ankle proprioceptive exercise on static and dynamic balance in normal adults. J Phys Ther Sci. 2017;29(2):242-4.

180. Ribot-Ciscar E, Milhe-De Bovis V, Aimonetti JM, Lapeyssonnie B, CampanaSalort E, Pouget J, et al. Functional impact of vibratory proprioceptive assistance in patients with facioscapulohumeral muscular dystrophy. Muscle Nerve. 2015;52(5):780-7

181. Ribot-Ciscar E, Aimonetti JM, Azulay JP. Sensory training with vibrationinduced kinesthetic illusions improves proprioceptive integration in patients with Parkinson's disease. J Neurol Sci. 2017;383:161-5.

182. Ackerley R, Aimonetti JM, Ribot-Ciscar E. Emotions alter muscle proprioceptive coding of movements in humans. Sci Rep. 2017;7(1):8465.

183. Papaioannou S, Dimitriou M. Muscle spindle function in muscular dystrophy: a potential target for therapeutic intervention. J Physiol. 2020;598(8):1433-4.

\section{Publisher's Note}

Springer Nature remains neutral with regard to jurisdictional claims in published maps and institutional affiliations.
Ready to submit your research? Choose BMC and benefit from:

- fast, convenient online submission

- thorough peer review by experienced researchers in your field

- rapid publication on acceptance

- support for research data, including large and complex data types

- gold Open Access which fosters wider collaboration and increased citations

- maximum visibility for your research: over $100 \mathrm{M}$ website views per year

At $\mathrm{BMC}$, research is always in progress.

Learn more biomedcentral.com/submissions 